\title{
Early Modern Military Architecture in the Ottoman Empire
}

\author{
H. Burcu Özgüven
}

Published online: 3 September 2014

(C) Kim Williams Books, Turin 2014

\begin{abstract}
Strongholds with firearms remained significant in the Ottoman frontier from the fifteenth until the nineteenth century. The employment of firearms technology resulted in military strongholds at strategic passages. That Sultan Mehmed II employed large cannons effectively during the siege of Constantinople was reported by many eyewitnesses. Sultan personally inspected firearms, from the foundry and ballistic calculations, to topographic position and related administration. There existed various European experts and craftsmen in the Ottoman palace who also contributed to the Ottomans' use of cannons. Fortifications in the third quarter of the fifteenth century were equipped with cannons and other firearms, and architecture as well was created according to the new technology. This article discusses how Kilidül Bahir and other fortifications arrived at their unique geometry in the fifteenth century by taking historical accounts and illustrations as documentary evidence. It shows that fifteenth-century Ottoman military architecture follows a clear path where logical translation from firearms technology to the architecture can be observed.
\end{abstract}

Keywords Ottoman architecture - Military architecture - Fortification · Firearms · Cannon · Kilid-ül Bahir · Rumeli Hisar · Anadolu Hisar ·

Yedikule $\cdot$ Mehmed II (the Conqueror)

\section{Introduction}

"There must exist only one emperor in the world, one faith and one kingdom.." Mehmed II (1432-1481) assured his status among the historical figures after his first

H. B. Özgüven $(\bowtie)$

Department of Architecture, Faculty of Architecture, Trakya University,

Edirne 22030, Turkey

e-mail: bozguven@hotmail.com 
great achievement, the conquest of Constantinople in 1453 (Thomas 1868: 11). ${ }^{1}$ His siege strategy was accomplished by the support of nascent gunpowder technology. This had been practiced in the age of Murad II, Mehmed's predecessor, during the siege in Hexamillion around Peloponnes (1438-39) where bronze cannons were produced directly on the site (Mehmet Neşri 1957: 633). In the Battle of Varna (1443-44) Ottoman troops observed that the Hungarians had placed wheeled carts on the battleground in a circular arrangement to form a ready-made moveable fortress with firearms and light cannons placed in between the carts, an arrangement known as a tabor or Wagenburg (Fig. 1a). Previously, the Ottomans had arrived at the idea of placing the weapons on a certain geometrical structure (havale) and here they employed tabor which affected later temporary structures in the scene of war (Anon 1987: 59-60, 68; Uyar and Erickson 2009). Strongholds with firearms were to remain significant in the Ottoman frontier until the nineteenth century (Özgüven 2009). Employment of firearms technology resulted in the construction of geometric military strongholds at the strategic passages (Figs. 2, 3). This article focuses on the early phase of the Ottoman military architecture, especially on Mehmed II's characteristic Kilid-ül Bahir around the Dardanelles and discusses how this fortification reached to its unique geometry in the fifteenth century.

\section{Mehmed II and the Early Modern Firearms Technology}

Mehmed II's reference to military geography was based on the ancient literary sources. Treatises such as a translation of the Cosmographia by Claudius Ptolemeus belonged to his exceptional library collection, as well as the histories written by Titus Livius (Ab urbe condita libri) and Quintus Curtius (Historiae Alexandri Magni) (Thomas 1868: 9-10; Raby 1983). ${ }^{2}$ A Byzantine eyewitness of his age, Kritovoulos of Imbros, pointed out Mehmed's interest in antiquity, especially in the ancient Trojan War, as he commented that the Turks revenged the Trojans' defeat by controlling the western Anatolian region against the colonies (Kritovoulos 1954: 14, nr. 23). ${ }^{3}$

Sigismondo Malatesta of Rimini (1417-68) presented one of the manuscripts of Roberto Valturio's (1405-75) De re militari to the Sultan with a letter in 1463. Also its first printed version (1472) was among the collections of the Topkap1 Palace

\footnotetext{
${ }^{1}$ Original words as quoted by Zorzi Dolfin were in fol. 313: "Hora dice esser mutato le saxon di tempi, si che de oriente el passi in occidente, come gli occidentali in oriente sono andati, uno dice douer esser lo impero del mundo, una fide, una monarchia".

2 Original words by Dolfin were in the same fol.: "El signor Maumetho gran Turco, e zouene d'anni 26 (...) aspirante a gloria quanto Alexandro Macedonico, ogni di se fa lezer historie romane, et de altri da uno compagno d. 'Chriaco d'Ancona, et da uno altro Italo, da questi se fa lezer Laertio, Herodoto, Liuio, Quinto Curtio, Cronice de i papi, de imperatori, de re di Franza, de Langobardi; usa tre lengue turco, greco, et schiauo".

3 Europeans at that time believed that Turks were the direct descendants of the Teucres people whose ancestors were Trojans. However this was another facet, yet psychological, of the war strategy, as Mehmed II tried to justify his conquest plan towards the Italian city states.
} 


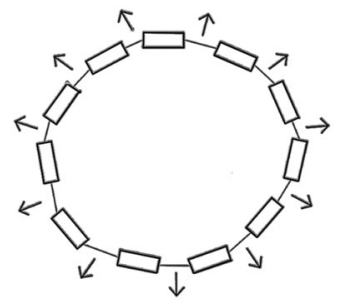

A

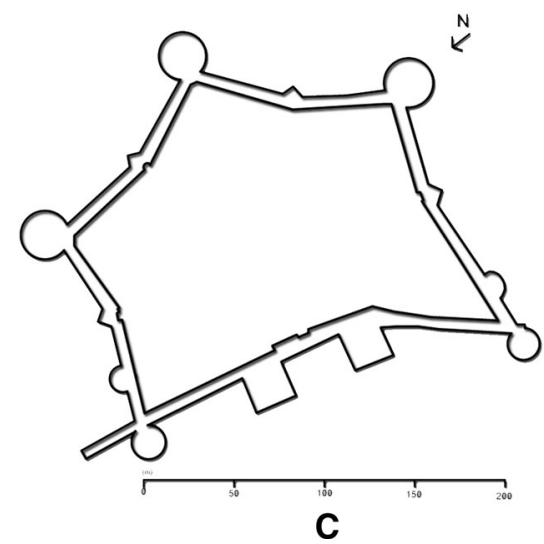

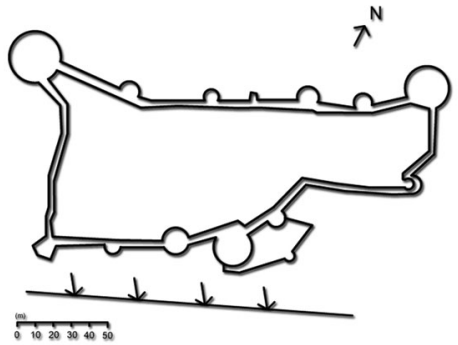

B

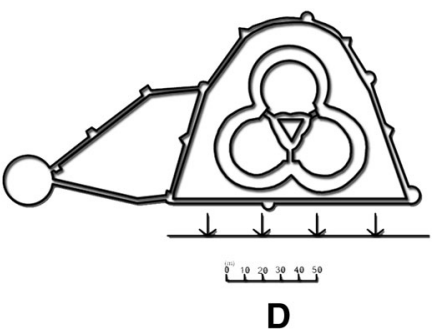

Fig. 1 Comparative schematic drawings of fortress plans: a a hypothetical tabor, b Rumeli Hisar, c Yedikule, d Kilid-ül Bahir. Drawings: author

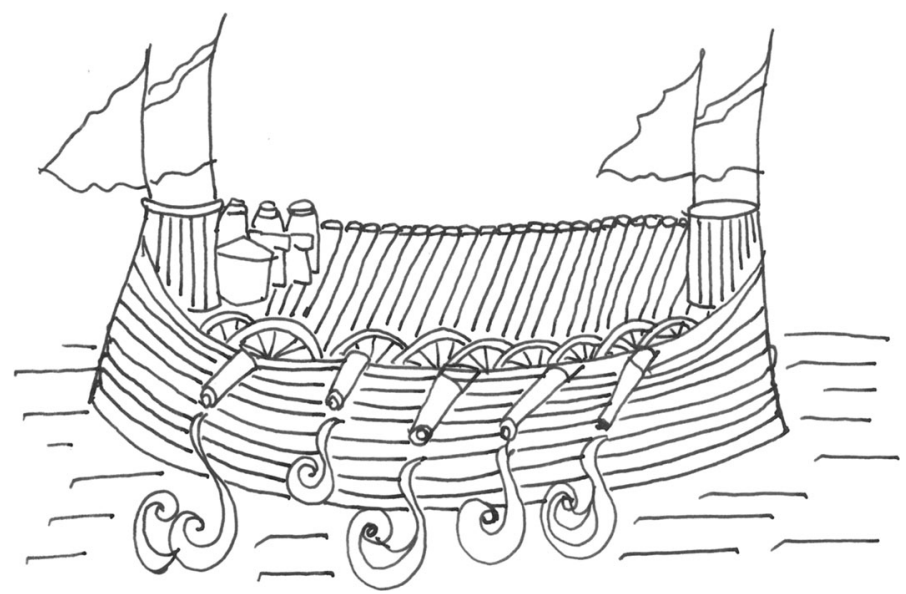

Fig. 2 A havale type of fortress from the siege of Szigetvar (1566), by Matrakçı Nasuh. Drawing: author, after the MS. Nüzhet-el-Esrar-el-Ahbar der Sefer-i Sigetvar by Ahmet Feridun Paşa. Original in: Topkapi Palace Library, H-1309 
Fig. 3 Miniature of a fortress model in a festival parade (around 1720). From: (Nutku 1987), res. 55, after 'Surname-i Vehbi'. Original manuscript is the in Topkapı Palace Museum Miniature Collection, Inv. A 3593. The book is the collection of miniature illustrations by Levni

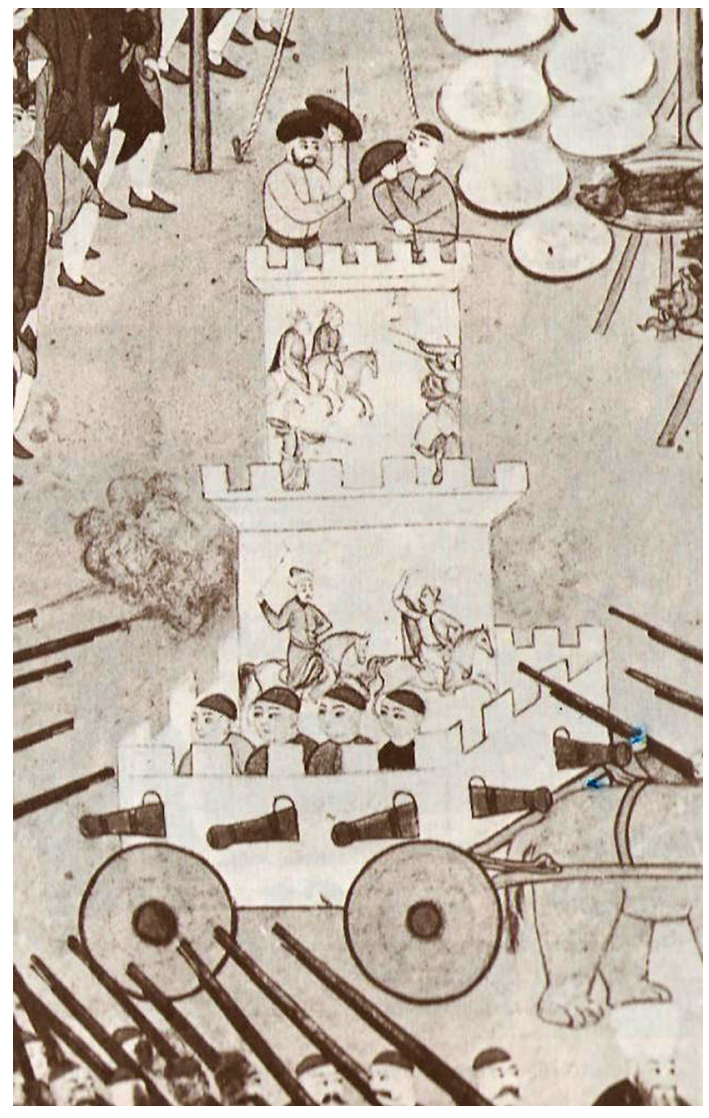

(Sihey 1937; Raby 1982: 4). ${ }^{4}$ Another manuscript Sigismondo might have presented was the book of Mariano Di Iacopo, il Taccola, De machinis in Latin (Raby 1983: 16; Fane 2003).

Within the Ottoman palace circle there were also European experts and craftsmen who practiced the new technology. Before the conquest of Constantinople an envoy of Janos Hunyad, the king of Hungary, came to the Ottoman encampment and helped to improve bombardment techniques (Dukas 1956: 167-168). Another Hungarian, Master Urban produced a super large cannon in Edirne, the capital at that time, however this trial resulted with his accidental explosion (Dukas 1956: 151-154). Germans, such as Jörg of Nüremberg joined the Ottoman army as cannon master (Büchsenmeister) after 1456 (Vasiliev 1935), as well as Master Georg from Meissen (Babinger 1973: 396-7). Some histories also refer to Sadi Pasha, who was

\footnotetext{
${ }^{4}$ Valturio's De re militari appears as the earliest treatise on the Renaissance artillery technology. Illustrations of the first versions were made by Matteo de' Pasti. The book was re-printed several times. Sihey also adds that a letter to Mehmed II written in Latin was found within a manuscript in Murano (probably in the library of S. Michael Monastery) and here Malatesta wrote that Matteo de' Pasti was in charge to present Valturio's manuscript to the Sultan. On the other hand, Raby underlines that de' Pasti was arrested by the Venetians and the mission was 'aborted'.
} 
trained as an expert of warfare technology in Europe (Evliya Çelebi 2006: 44), and also to a Münir Ali, who probably produced large cannons in the Tophane Foundry around 1464. All aspects of firearms were inspected by the Sultan personally, from the foundry to ballistic calculations, from topographic position to related administration. Kritovoulos adds that he even determined the exact location of the artillery during the siege of Constantinople (Kritovoulos 1954: 51-52).

Traditional weapons were still used on the war scene, but the actual destruction of the Byzantine city walls was achieved by the large, bronze shahi type of cannons, which were circa five meters long, weighed nineteen tons and fired a stone projectile weighing $500 \mathrm{~kg}$. The calibre of the bronze cannon was roughly 1,200 m and its explosion could be heard within an area of $25 \mathrm{~km}$ (Fig. 4). Two separate parts of the shahi cannon could be integrated by screwing (Lefroy 1870; Högg 1932; Goodwin 1971: 103-106). Large cannons of this type were later called 'Dardanelles Guns', and an example is now on display at Fort Nelson in Hampshire, UK. They were used at the Kilid-ul Bahir and Kal'a-i Sultaniye Fortresses in Çanakkale. In the sixteenth century the reputation of the Ottoman cannon production reached other lands as far away as India.

\section{Military Structures in the Fifteenth Century}

\section{Rumeli Hisar}

Firearm technology not only changed fundamentals of warfare but also triggered a revision of medieval rules of the military architecture. After the demolition of the mighty walls of Constantinople, which had been impossible to breach before, the superiority of firearms was fully recognized. It was obvious that defenses should be planned according to new developments, such as the production of artillery, its transportation and range of the bombardment. Strongholds were no longer considered as places for defensive actions alone, but also took part in offensive actions where troops within controlled the outside environment by bombardment. An early examination of this method was the Rumeli Hisar, a pre-conquest fort on the European shores of Bosphorus (Fig. 1b). Rumeli Hisar was built in 1452 as the counterpart to the Anadolu Hisar at the Asian side (1399). Here the Bosphorus became most accessibly at its narrowest point. Original site selection was attributed to Sultan Bayezid I, who probably pioneered the first siege plan, but the war against Timur postponed the conquest of Istanbul for a half century.

Rumeli Hisar's fundamental function was 'to cut the throat' of the Bosphorus, that is, to block the pro-Byzantine ships, mainly under the Venetian or Genovese flag, by cannon bombardment both from the European and Asian sides. The characteristic double currents of the Bosphorus became especially helpful during the springtime, where ships could have been threatened by dangerous whirlpools and eddies in vicinity of the Hisar. Sultan's plot was to attack the ships passing by and to force them to navigate towards the 'diabolical' whirlpools of the Bosphorus, where they were eventually expected to sink (Barbaro 1856; Kritovoulos 1954: 19). This 


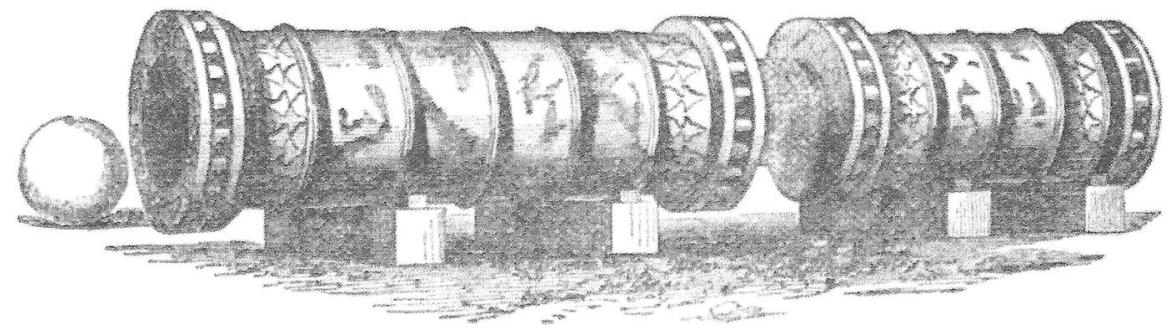

Fig. 4 Shahi cannon of Mehmet II. Image: Lefroy (1870, p. 214)

tactic was used during the siege of Istanbul, when some Venetian ships tried to flee from the heavy bombardment.

Rumeli Hisar is located on a steep slope towards the Bosphorus shore and its architecture accorded with the actual strategy of the conquest. The overall structure was designed according to topographical necessities, rather than the geometric planning rules. Three principal round towers, one in front and two in the rear, were tied together by the curtain walls and smaller bastions. The average radius of the main towers reaches approximately $24 \mathrm{~m}$ and the heights range from 20 to $24 \mathrm{~m}$. There was also an outer, smaller screen wall next to the shore, which the Ottomans called hisarbeçce ('baby fortress'). There is an angular bastion on the south eastern corner where a scarped wall bottom can be seen.

Fifteenth-century chroniclers from various origins, such as the Ottoman Tursun Bey, the Italian Niccolo Barbaro and the Byzantine Mihail Dukas, report that there were large cannons were placed at 18 openings of the screen wall, as well as loopholes created for the gun fire. That the Rumeli Hisar was equipped with firearms was confirmed by a Venetian illustration that presumably dates from 1452 , showing the cannons carefully depicted in detail (Babinger 1955). Dukas underlines that there also existed one large cannon on the front tower, that is, the southeastern bastion close to the Bosphorus where today the slight slope on the bottom part of the wall can be seen. The cannon was probably dismantled and relocated to the top of the tower.

Rumeli Hisar represents the early phase of Ottoman fortification architecture where cannons were placed and utilized. Beginning with the Hisar Ottomans employed firearms within the fortification units. Thereafter the strongholds became offensive in character. This can also be related to the Renaissance ideas about war with which young Sultan was intimately acquainted.

Regarding the south eastern bastion of the Rumeli Hisar1, a nearly simultaneous example was the Porta Maggiore Bastion on the walls of Fano by the architect Matteo Nuti da Fano (1464-69). The scarp reflects precaution against the cannon bombardment, and the structure was related to the rest of the fortification to some extent. Another sophisticated example is the Rocca Roveresca in Mondavio by Francesco di Giorgio Martini (1482-92). The approach that separate structures could have operated as independent units was to be revised by the designers of triangular bastions towards the end of the fifteenth century (Derchert 1990). 
Yedikule

After the conquest of Constantinople the Sultan gave priority to official construction projects such as Yedikule and his first seraglio, Saray-i Atik. Yedikule, Fortress of Seven Towers, was erected as the official treasury fort of the Empire around the year 1457 (Özgüven 1996: 95-99). ${ }^{5}$ Witnesses described the building as one of the palaces of the Sultan. Each tower of the Yedikule functioned as the storage of precious goods, documents, armoury, coins, and golden and silver ingots. Sultan knew well from his ancestors that protection of the fort was one of the high-priority matters of state (Clavijo 1970: 187-188). ${ }^{6}$ That the structure was built as a fortress points out the existence of a military outpost in charge of defending the official treasury against hostile attacks. The treasury was later transferred to the inner section of the Topkap1 Palace in the sixteenth century and thereafter Seven Towers became the prison of prestigious captives.

Yedikule was built on the shores of the Marmara Sea, at what was formerly the principal entrance gate to the city. Two towers and two pylons of the former Porta Aurea, the triumphal arch, were inherited from the Byzantine city walls. Three original round towers were added for creating an almost pentagonal plan (Fig. 1c). When a line is drawn from the midpoint of the former Porta Aurea towards the Ottoman tower in the middle, the axis divides the fortress in two symmetrical parts (Fig. 5). A small domed structure, the Conqueror's Mosque, appears as the focal point of the fortress courtyard, which also marks the midpoint of the axis of symmetry (Gabriel 1943).

The pentagonal structure of Yedikule reflects another development in Ottoman geometric fortress architecture. It was likely built for the Sultan's respect towards geometric shapes as the site plan of his religious charitable complex was also designed in strict rationality (1462-70) (Kuban 1980: 143-144). Love of symmetry and axiality might be evaluated as a radical shift from the early Ottoman architecture. Later examples of building complexes with rational site plans were best executed by the architect Sinan at the imperial mosques.

Art historians proposed that the famous Florentine architect Antonio di Pietro Averlino, also known as Filarete (1400-ca. 1469), might have declared his vision of geometry to the Sultan. In his Trattato di architettura (written ca. 1460-1464) Filarete described the ideal city Sforzinda as a representation of coherent design. Mehmed II was certainly a person who looked to the West for inspiration; he also looked to the Ilkhanid traditions in the East. As pointed before, he exchanged letters with Malatesta, writing of his intention to employ Italian artists and decorators for his new palace, as well as with the Venetians during the peace period. However, no

\footnotetext{
5 Yedikule's central role might be understood through its guards rank at the protocol. The chief guard of the Yedikule (dizdar) was in charge of protecting keys and he was among three people in the empire who were allowed to talk with sultan personally (the two others were the grand vizier and sultan's official mother).

${ }^{6}$ Devastation of the Ottoman treasury occurred when Bayezid I was taken captive by Timur's army in 1402. Vulnerability of another fort was observed when the Ilkhanate treasury outpost Göksaray was quickly plundered after Timur's death in 1405. These cases might have been moral for Mehmed II who planned to safeguard financial sources of the state he fundamentally reorganized.
} 


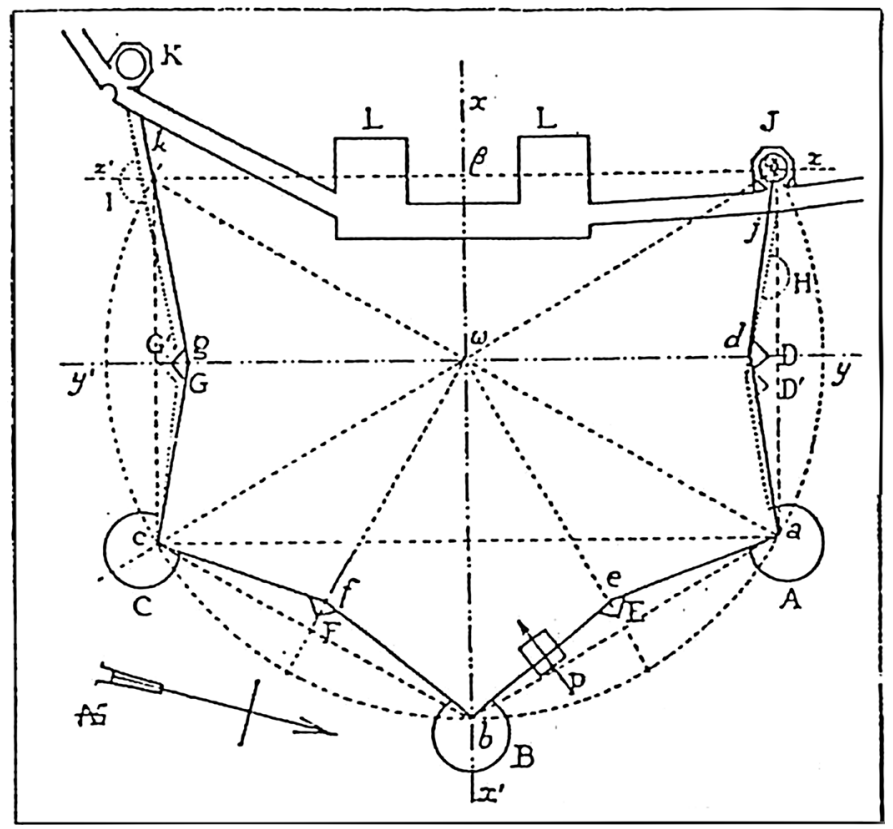

Fig. 5 Geometrical analysis of Yedikule. Image: author, after Gabriel (1943)

historical evidence has been found of the existence or influence of a foreign architect during Mehmed II's lifetime.

Florentine sculptor Bertoldo di Giovanni and the sculptor and medallist Matteo de' Pasti from Verona were two artists who probably served the court, as did the painter and medallist Gentile Bellini from Venice, who created the portrait of Mehmed II and depicted many scenes from the Ottoman daily life in 1479-80 (Karabacek 1918: 48-50). Bertoldo's medallion illustrates the Conqueror as a barebreasted Roman war lord holding a figurine his upraised hand. The 'three graces' behind him represent his three principal conquests, Asia, Trebizond and Greece, carried as captives in the chariot of war led by cold and merciless Mars (Karabacek 1918: 51). This symbolic representation also reflects the changing approach of Ottomans, who began to perceive the conquered lands in unity which helped to found the permanent system of a centralized state with the set of laws and codes. ${ }^{7}$

\section{Kilid-ül Bahir}

Kilid-ül Bahir represents the further step of geometrical approach in the Ottoman military architecture. The Dardanelles, once also known as il braccio di San Giorgio ('the arm of St George'), was the second strategic sea passage providing access to Istanbul, after the Bosphorus. In antiquity, Sestos on the European side and Abydos

\footnotetext{
7 The new approach towards the state system was represented by the kanunname al-i Osman during the reign of Mehmed II, as the earliest Ottoman codex, which was revised and enlarged by later sultans.
} 
(today Çanakkale) on the Asian side were the legendary twin towns on the shores of Dardanelles (Teply 1968: 239).

Kilid-ül Bahir was erected as one of the opposite fortresses between the ancient port of Madytos and the ancient city of Eleous (1461-62). According to Kritovoulos "the Sultan sent men to examine the lay of the land and the swiftest current on the strait" (Kritovoulos 1954: 186, nos. 92-94). The purpose of the construction was again to control the crossing of ships by an effective use of firearms. The narrowest point of the strait, about 1,300 m, was between Kilid-ül Bahir and Kal'a-i Sultaniye, the fortress opposite.

Kilid-ül Bahir could be described as the crystallization of early Renaissance military theories, from the point of its central plan, offensive character and extensive use of artillery. The trefoil or clover-leaf plan of the inner fortress is surrounded by a screen wall (hisarbeççe), flanked by another tower which was probably built in the sixteenth century, as the illustrations reveal (Fig. 1d). There were certain additions to the fortress depicted by the European witnesses in the sixteenth and seventeenth centuries (Özgüven 1996: 122-124). ${ }^{8}$ The clover-leaf inner-fortress of the Kilid-ül Bahir has three semi-circular walls, where the inner half-radius of each extends to about $13 \mathrm{~m}$. These walls give the geometrical characteristics of the fortress. They are approximately $7 \mathrm{~m}$ thick and $18 \mathrm{~m}$ high. A triangular inner tower, which can be compared with medieval keeps, rises nearly to $30 \mathrm{~m}$ in height, and walls here are $3.7 \mathrm{~m}$ thick. The wall-walk some $6 \mathrm{~m}$ wide was protected by an inverted banquette probably facilitated the firing of guns (Ayverdi 1974: 739-804; Utkular 1953: 27-38). According to an Ottoman miniature in the Correr Museum (drawn in the early seventeenth century) a settlement with densely placed houses and a main mosque could be observed on the area between the enceinte and original fortress (Fig. 6). This was probably a seventeenth-century military outpost mainly inhabited by soldiers, of the kind organized at many Ottoman frontier fortifications bordering on the European territory. Similar military neighborhoods were also created in the Rumeli Hisar, Anadolu Hisar, Yedikule and Kal'a-i Sultaniye, on the Asian shore of the Dardanelles.

Reinforced by the artillery power, Kilid-ül Bahir reflects the offensive character of the early modern military fortifications. Architectural details, such as outer walls, strategic towers for placing cannon, and its unique geometry made of basic shapes, integrate functional, architectural and topographical characteristics. Historical sources, such as Reinhold Lubenau, Peter Mundy and Edmund Chishull confirm the military character of the fortification (Özgüven 1996: $120 \mathrm{ff}$ ). They also describe some thirty cannons directed towards the sea passage. Illustrations by Piri Reis, Guillaume-Joseph Grelot, Luigi Ferdinando Marsigli and Jérôme Maurand show military installations, and the Correr miniature also displays artillery placement in detail (İtalyan Kültür Merkezi 1995). Here the shahi type cannons were placed at the screen wall openings and surrounding towers, with a smaller type in the inner fortress. The barrels were directed towards the surrounding area and the sea.

\footnotetext{
8 The sequence of the illustrations, European and Ottoman, reveal that the original fortress was reinforced by new additions in accordance with the military purpose, but later revisions seem to conceal its original geometric plan.
} 


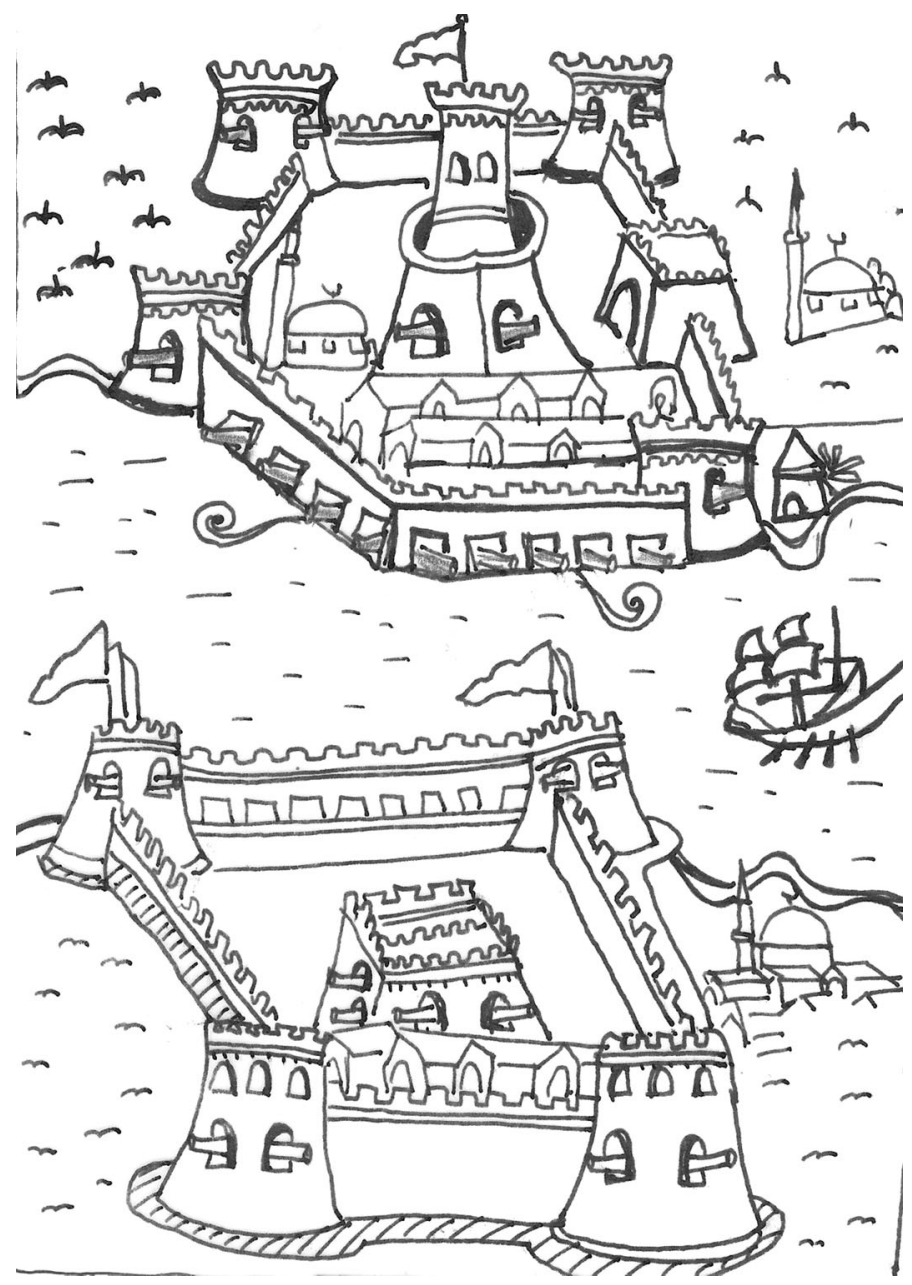

Fig. 6 Kilid-ul Bahir and Kal'a-i Sultaniye, miniature drawing, early seventeenth century. Drawing: author, after İtalyan Kültür Merkezi (1995)

Regarding the narrowest point of the Dardanelles Strait, the projectiles of large cannons were aimed towards the opposite shore in case of an attack. Artillery bombardment could have attacked and destroyed a fleet from both sides. The strategy was practiced long after its organisation. In 1807 a British fleet was bombarded by the Dardanelles guns, which were still active after 350 years.

Whether or not the clover-leaf plan of Kilid-ül Bahir also had a symbolic meaning could be debated, but there is no documentary evidence to prove it. There is also no reason to believe that the fortress plan represents the European trefoil shape or the three-lobed Ottoman motif known as çintemani. This unique plan apparently reflects the logical consequence of military necessities. Unfortunately its architect is unknown. 
An interesting equivalent to the Kilid-ül Bahir can be observed in a later example, the coastal artillery fortress of King Henry VIII in St. Mawes, England (built in the 1540s) (Tuulse 1956: $119 \mathrm{ff}$; Hughes 1982). The geometrical planning of St. Mawes Fortress, with its three semi-circular bastions with artillery platform and an inner round tower, shows the use of early modern firearms technology. Its upper terrace with inverted parapet wall recalls Kilid-ül Bahir's banquette. St. Mawes and its counterpart, Pendennis Castle, were situated on both coasts of the Falmouth Harbour in Cornwall. Both fortresses were probably constructed to assure the protection of further strategic coasts.

\section{Conclusion}

The Ottoman employment of the tabor during the battle of Varna resulted in various types of military structures. It was found out that the circular form facilitated the use of artillery towards the surrounding area. This practice had an architectural outcome, that is, the building of round towers reinforced by firearms, such as the Rumeli Hisar around Istanbul. The idea was also applied to the round towers of Yedikule, the treasury fortress of the empire.

Mehmed the Conqueror's desire to take control over territory was proven by his interest in cartography. Indeed, the conquest of Istanbul changed the role of the Ottomans, who began to lay the foundations of the centralized state system. The early modern attitude to shape the architectural space with basic forms of geometry reflects the pursuit of unity in architecture. That the sultan was deeply interested in geometrical forms is shown by the religious imperial complex, Fatih Külliyesi. The complex features the first geometrically rational and symmetrical layout in Ottoman architecture. Here the monumentality of the central mosque was reinforced by symmetrical eight medreses. A rational aesthetic and geometric attitude are even better represented in the monumental religious building complexes than in the military architecture.

As one of the early modern fortifications, Kilid-ül Bahir, reflects the tendency towards geometrical rationality, as well as the logical translation of the firearms technology to Ottoman military architecture. The fortress represents a linear development that began with the tabor and placement of cannons at key points in the strongholds, and extended to the overall fortress design where the offensive strategy was based on firearms.

The crucial importance of Kilid-ül Bahir as a naval outpost lasted until new fortifications were built at the Dardanelles in the seventeenth century. However, its geometrical form remained peculiar to the era of Mehmed the Conqueror. Its unique architectural plan was not repeated in later military fortifications; instead, the layout of its twin, Kal'a-i Sultaniye on the Asian shore, which was designed as a rectangle with round towers at the corners, became almost standard for later military structures. 


\section{References}

Anon. 1987. Gazavat-ı Sultan Murad bin Mehemmed Han: İzladi ve Varna Savaşlarl (1443-1444) (Üzerinde Anonim Gazavatname), eds. Halil İnalcik, M. Oğuz. Ankara: TTK.

Ayverdi, Ekrem Hakk1. 1974. Osmanlı Mimarisinde Fatih Devri 855-881 (1451-1481) 4. İstanbul: İstanbul Fetih Cemiyeti Yayınları.

Babinger, Franz. 1955. Ein Venedischer Lageplan der Feste Rumeli Hisary, 188-195. LVII: La Bibliofilia.

Babinger, Franz. 1973. Mehmed the Conqueror and his time. Princeton: Princeton University Press.

Barbaro, Niccolo. 1856. Giornale dell'assedio di Costantinopoli, ed. E. Cornet. Vienna.

Clavijo, R.G. 1970. Narrative of the Embassy of R.G. Clavijo to the Court of Timour at Samarcand A.D. 1403-6 (reprint), ed. C.R. Markham. New York.

Derchert, Michael S.A. 1990. The military architecture of Francesco di Giorgio in southern Italy. Journal of Society of Architectural Historians XLIX(2): 161-180.

Dukas, Mihail. 1956. Bizans Tarihi, ed. Vladimir Mirmiroğlu. Istanbul.

Evliya Çelebi. 2006. Evliya Çelebi Seyahatnamesi, eds. I.R. Dankoff, S.A. Kahraman, Y. Dağli. Istanbul: YKY.

Fane, Lawrence. 2003. The invented world of Mariano Taccola: revisiting a once-famous artist-engineer of 15th-century Italy. Leonardo 36(2): 135-143.

Gabriel, Albert. 1943. Chateaux turcs du Bosphore. Paris.

Goodwin, Godfrey. 1971. A history of Ottoman architecture. London: Thames and Hudson.

Högg, Hans. 1932. Türkenburgen an Bosphorus und Hellespont. Dresden.

Hughes, Quentin. 1982. The British use of bastion fortifications. IBI Bulletin (Europa Nostra). 40(1982): 51-69.

İtalyan Kültür Merkezi (ed.). 1995. Yüzyllar Boyunca Venedik ve İstanbul Görünümleri-Vedute di Venezia ed Istanbul Attraverso $i$ Secoli. Istanbul.

Karabacek, Josef von. 1918. Abendländische Künstler zu Konstantinopel im XV. und XVI. Jahrhundert. Wien: Buchhändler der Kaiserlichen Akademie der Wissenschaften.

Kritovoulos of Imbros. 1954. History of Mehmed the Conqueror by Kritovoulos (1451-1467), ed. Charles Riggs. Princeton: Princeton University Press.

Kuban, Doğan. 1980. Architecture of the Ottoman period, pp. 137-170. In The art and architecture of Turkey, ed. E. Akurgal. Oxford: Oxford University Press.

Lefroy, J.H. (Major General). 1870. An account of the Great Cannon of Muhammad II. Recently presented to the British Government by the Sultan, with notices of other Great Oriental Cannon. In Minutes of proceedings of the Royal Artillery Institution VI, pp. 203-227.

Mehmet Neşri. 1957. Kitab-ı Cihannüma, II, eds. Faik Reşit Unat, M.A. Köymen. Ankara: TTK.

Nutku, Özdemir. 1987. IV. Mehmed'in Edirne Şenliği (1675). Ankara: Türk Tarih Kurumu Basımevi.

Özgüven, Burcu. 1996. Barut ve Tabya: Rönesans Mimarisi Bağlamında Fatih Sultan Mehmet Kaleleri (Gunpowder and bastion: fortifications of Mehmed the Conqueror as compared with the renaissance architecture) (unpubl. Ph.D. diss). Istanbul: Istanbul Technical University.

Özgüven, Burcu. 2009. Palanka forts and construction activity in the Late Ottoman Balkans. pp. 171-187. In The frontiers of the Ottoman world, ed. A.C.S. Peacock. London: Oxford University Press.

Raby, Julian. 1983. Mehmed the Conqueror's Greek scriptorium. Dumbarton Oaks Papers 37: 15-31.

Raby, Julian. 1982. A sultan of paradox: Mehmed the Conqueror as a patron of the arts. The Oxford Art Journal 5(1): 3-8.

Sihey, Yaşar. 1937. De re militari 'Askeri şeylere ait'-bu kitabı Fatih 465 sene evvel getirtmişti. Cumhuriyet (28th March 1937).

Teply, Karl. 1968. Kaiserliche Gesandtschaften ans Goldene Horn. Stuttgart: Herausgeber der Bibliothek klassischer Reiseberichte.

Thomas, Georg Martin (ed.). 1868. Belagerung und Eroberung von Constantinopel im Jahre 1453 aus der Chronik von Zorzi Dolfin. In Sitzungsberichte der Bayerischen Akademie der Wissenschaften, phil. hist. Klasse II, München.

Tuulse, Armin. 1956. Castles of the western world. Vienna: Prestel Publishing.

Utkular, İsmail. 1953. Çanakkale Boğazında Fatih Kaleleri. İstanbul: İstanbul Teknik Üniversitesi Yayınlar1.

Uyar, Mesut, and EdwardJ Erickson. 2009. A military history of the Ottomans; from Osman to Atatürk. In $A B C$-CLIO, ed. Santa Barbara. Calif: LLC. 
Vasiliev, A. 1935. Jörg of Nüremberg-a writer contemporary with the fall of Constantinople (1453). Byzantion 1935: 205-209.

Burcu Özgüven is Full Professor in the Faculty of Architecture at Trakya University, Turkey. She received a B. Arch (1987) from Istanbul Technical University, MA (1990) from Bosphorus University and Ph.D. (1997) from ITU on the fortifications of Mehmed the Conqueror. She is the author of Osmanll Macaristan'inda Kentler Kaleler (Towns and Fortifications in Ottoman Hungary, 2001) and various articles on the Ottoman architectural history, including military architecture. She has conducted research in Florence, Vienna, Famagusta and Edirne. Her principal research area is the Ottoman and early Republican Turkish architecture as compared with the European tendencies. She currently works on the urbanization of Istanbul during the 30s and serves as the Dean of the Faculty of Architecture. 